\title{
Speech Acts in EFL Classroom at Islamic Senior High School (MAN) 1 Sinjai
}

\author{
Juvrianto CJ \\ Juvrianto.chrissunday@yahoo.com \\ Graduate Program of English Education, State University of Makassar
}

\begin{abstract}
Speech act takes a significant role in the whole process of teaching and learning process by the teacher and students. In line with this topic, this study aims to observe more about the use of speech act by the teacher and students in their interactions in EFL (English as a Foreign Language) classroom. This study shows that there are three kinds of speech acts performed by the teacher and students: locutionary act, illocutionary act and perlocutionary act. Those speech acts are supported by theories of J.L Austin who investigated and invented the use of speech act. The result of the study indicates some uses of speech act performed by the teacher and student which is elaborated into extract explaining more about the use of speech act in EFL classroom. Locutionary act performed by the teacher and students is used when they are conveying an expression without any specific intention within. On the other hand, illocutionary act is committed by them when they are communicating some expressions containing a certain intention to the listener. Perlocutionary act is performed by the teacher and students while they are conveying expressions and the listener will show a response and act as feedback to what the speaker says. Hopefully, the study will help both teachers and students in the implementation of good communication.
\end{abstract}

Keywords: speech acts, teacher and student interaction, EFL classroom.

\section{Introduction}

The classroom speech acts determine the quality of verbal interaction in the classroom. This provides important information for teachers, whereby they know the typical teaching behaviors they use extensively in communicating with the students. Wells (1985) acknowledges that language use is related to the context in which the interaction takes place. The children use more 'control speech' as a set of different directives, commitments and declaratives during pretend play, especially when children play with peers.

Speech act performs when people make utterances such as apology, greeting, request, complaint, invitation, compliment, or refusal. The study of speech act is very importance for us. One of them is to make us comprehend the message discovered in every utterance.
In comprehending the message discovered in every expression we hear, Austin (1967) introduces the concept of illocutionary acts, and carefully distinguished them from locutionary acts and perlocutionary acts. Locutionary acts include phonetic acts, phatic acts, and rhetic acts. Phonetic acts are acts of pronouncing sounds, phatic acts are acts of uttering words or sentences in accordance with the phonological and syntactic rules of the language to which they belong, and rhetic acts are acts of uttering a sentence with sense and more or less definite reference. Perlocutionary acts are, on the other hand, acts attributed to the effect of uttering a sentence.

The study of speech act has been done by a couple of researchers in the different field of communication. The first research related to speech act was conducted by Nadar (1998). He 
focused his research on finding out speech acts he found in Indonesian learner's request in English. He found learner's preference in using certain request forms, terms of addressing, request perspectives, and linguistic devices for internal and external request modifications. The result also seemed to indicate learners' preference for adopting negative politeness strategy in making their requests.

The second research related to speech act was conducted by Farisi et al. (2013). They focused their research on analyzing the speech act produced by elementary school teachers and students to facilitate teaching and learning at SDN 10 Pringgasela East Lombok. From their study, they found that the teachers produced more utterances than students to explain certain thing to the students and asked the them to do or not to do something. It seems that the teachers used such utterances as directives function in which the teachers control and regulate the students. Besides, they also concluded that the frequency of teachers' speech acts implied that the degree of directness in conducting the teaching and learning was high. However, this was considered appropriate since the intention was to benefit the students.

The previous studies that have been elaborated above are similar as the writer's research in the field of speech acts. The difference of the previous studies and this study lies on the sample that will be discovered and focus of the study. The sample of this study is taken from the students of Senior High School (MAN) 1 Sinjai and it will focus on speech act occurred in the classroom between students and the teacher. Based on the explanation above, the writer is interested in conductin a mini research project entitled "Speech Act in EFL Classroom at Islamic Senior High School (MAN) 1 Sinjai."

\section{Review of Related Literature}

In this part, the writer presents the review of related literature describing the speech act theories, Austin's speech act theories and Searle's classification, speech act's role in English language teaching and learning, and speech acts in classroom relating to the title of this research.

\section{Speech Act Theories}

The study of speech act is very importance for us to make us comprehend what message that is discovered in every utterance. Speech act is also decided by the language ability of a speaker to convey the message in communication if we can understand about the meaning of speech act with clearly. Thus, when we speak with other people in the communication or conversation, the speaker not only speaks the source (the utterance have not intention and goal), but also interprets the speaker's meaning to the hearer. Consequently, the speaker can make the hearer understand the meaning of that utterance. Speech act is performed in a conversation or dialogue by a speaker and hearers.

Speech can be studied in a communicative event. To analyze the speech events, it is clearly another way of studying how to understand more of communication than it is said. Therefore, we can do with words and identifying some of the conventional utterance forms we use to perform specific actions and we need to look at move extended interaction to understand how those actions are carried out and interpreted within speech event of utterance.

\section{Speech Act's Role in English Language Teaching and Learning}

On the basis of the speech act theory, some other approaches have been developed, such as Leech's Politeness Principle and Grice's Cooperative Principles. The politeness principle implies that people should minimize the expression of impolite beliefs and maximize the expression of polite beliefs. As for the Cooperative Principle, Grice introduces four maxims with sub maxims, which the interlocutors must follow to avoid misunderstanding and be successful communicators. These maxims involve the following: quality, quantity, relation and manner. Brown and Levinson extend the politeness theory, proposing bold-on record, off record, negative and positive politeness strategies. 
As the conception and realization of speech acts and politeness principles are different across cultures, language learners definitely need to know certain rules and norms of the target language. Otherwise, they may fail in understanding the members of the culturally different society. What is acceptable and normal in their native language may sound rude and unacceptable for the foreign community. Thus, a language teacher is required to take these facts into consideration and draw the students' attention to the cultural differences and the peculiarities of the target language. To illustrate, thanking in Indonesian is not as common as in English and often, Indonesian people say "thank you" when they are really thankful and when it is really necessary to do.

\section{Locutionary, Illocutionary and Perlocutionary Acts}

Austin reconsiders the senses in which "to say something may be to do something", and suggests that a speaker can simultaneously perform three acts in issuing an utterance: the locutionary act is the act of saying something with a certain sense and reference; the illocutionary act is the act performed in saying something, i.e. the act named and identified by the explicit performative verb. The perlocutionary act is the act performed by, or as a consequence of, saying something.

All three acts are usually performed at the same time. Austin distinguishes them for the sake of analysis. Within the locutionary act Austin distinguishes three subsidiary acts: a phonetic act of producing certain noises; a phatic act of uttering certain words belonging to a certain vocabulary, in a certain grammar with a certain intonation, etc.; and a rhetic act of using the sentence with a definite sense and reference (which together are equivalent to meaning).

\section{a. Locutionary Act}

This component of the speech act is probably the least ambiguous. Bach and Harnish (1979), commenting on Austin's work, point out that Austin distinguishes three aspects of the locutionary act. Austin claims that to say anything is: always to perform the act of uttering certain noises (a phonetic act), always to perform the act of uttering certain vocables or words (a phatic act), and generally to perform the act of using that [sentence] or its constituents with a certain more or less definite 'sense' and a more or less definite 'reference', which together are equivalent to 'meaning' (rhetic act).

From that division it follows that the locutionary act comprises other three "subacts": phonetic, phatic and rhetic. This distinction as well as the notion of locutionary act in general was often criticized by Austin's followers. Searle even completely rejects Austin's division and proposes his own instead (Searle, 1968: 405). Searle (1968) warns that Austin's rhetic act is nothing else but a reformulated description of the illocutionary act and he therefore suggests another term, the so-called propositional act which expresses the proposition (a neutral phrase without illocutionary force). In other words, a proposition is the content of the utterance.

\section{b. Illocutionary Acts}

Illocutionary acts are considered the core of the theory of speech acts. As already suggested above, an illocutionary act is the action performed by the speaker in producing a given utterance. The illocutionary act is closely connected to speaker's intentions, e.g. stating, questioning, promising, requesting, giving commands, threatening and many others. As Yule (1996: 48) claims, the illocutionary act is thus performed via the communicative force of an utterance which is also generally known as illocutionary force of the utterance. Basically, the illocutionary act indicates how the whole utterance is taken in the conversation.

Sometimes it is not easy to determine what kind of illocutionary act the speaker performs. To hint his intentions and to show how the proposition should be taken the speaker uses many indications, ranging from the most obvious ones, such as unambiguous performative verbs, to the opaquer ones. For example, it is among which mainly various paralinguistic features (stress, timbre and intonation) and word order should be mentioned. All these hints or factors 
influencing the meaning of the utterance are called Illocutionary Force Indicating Devices, or IFID as Yule, referring to previous Searle' s work, calls them (Yule, 1996: 49).

\section{c. Perlocutionary Acts}

Perlocutionary acts, Austin's last element in the three-fold definition of speech acts, are performed with the intention of producing a further effect on the hearer. Sometimes it may seem that perlocutionary acts do not differ from illocutionary acts very much, yet there is one important feature which tells them apart. There are two levels of success in performing illocutionary and perlocutionary acts which can be best explained on a simple example:

\section{"Would you close the door?"}

Considered merely as an illocutionary act (a request in this case), the act is successful if the hearer recognizes that he should close the door, but as a perlocutionary act it succeeds only if he actually closes it.

\section{Speech Acts in Classroom}

The language plays an important role in the teaching and learning process. It means that for children, school leads to confronting new ways of using and acquiring a certain language. When teaching is designed to accomplish a particular goal of learning, it might be successful with the use of a certain language. The teaching is carried out by language that is known widely as classroom speech act (Curtis and O'Hagan, 2005: 48). Searle (1969) defines speech act as the basic unit of language, the production of a token in the context of a speech act.

Classroom speech act involves all verbal utterances used as a medium in classroom communication. Research on speech acts produced in the teaching and learning process in the classroom has been known as discourse studies or discourse analysis. This research is concerned with the relationship between language and the context in which it is used (McCarthy, 1991:5, Seken, 2004:61). Cazden (in Hickman, 2000) identifies three general functions of language that make communication central in school, specifically in the classroom, which are through language teacher transmits curriculum, controls the communication, and reflects personal identity.

Considering the views described above, the present study focused on classroom interaction during the teaching and learning process in EFL Classroom at Islamic Senior High School (MAN) 1 Sinjai that includes investigation of: (1) types of the speech acts produced by the teachers and students, (2) functions of the speech acts produced by the teachers and students.

\section{Methodology}

In this present study, the researcher applied qualitative research. This model was suitable for this research since the source of the data was the teaching and learning activity in naturalistic environment of the classroom. Moreover, the data of this research were collected when the teaching and learning process was going on naturally. The researcher made the analysis by observing the linguistic behaviors of teachers and students in a classroom context. This research analyzed the speech acts produced by teachers and students of EFL classroom at Islamic Senior High School (MAN) 1 Sinjai as the subjects of this research.

The data were the conversations occurred in EFL classroom by the teacher and students. The collected data were analyzed as follows. First the writer recorded the classroom interaction between teacher and students for three meetings. Second, the writer transcribed the data which was in the audio form. Later on, the writer compared and analyzed the speech acts occurred in the classroom interactions.

\section{Findings: Types of Speech Acts in the EFL Classroom}

This part presents the findings of the research and the discussion of the research findings. The findings of the research are taken from the three meetings observation and cover the description of Speech Acts in EFL Classroom at Islamic Senior High School (MAN) 1 Sinjai. 


\section{Locutionary Acts}

Locutionary act comprises other three "sub-acts": phonetic, phatic and rhetic. This distinction as well as the notion of locutionary act in general was often criticized by Austin's followers.

In the present data, there are two examples detected in the teaching and learning in EFL classroom. Extract 1 takes place during the teaching process. When the teacher asked the students whether they bring their dictionary or not, she performed a locutionary act.

\section{Extract 1: \\ Teacher and students' interaction}

Teacher: Hai Ella why you look so sad. Ini menular ya sakitnya... bukan sakit. kayaknya galaunya Alif kemarin menular ke ella hari ini.

((Hey, Ella, why do you look so sad? This is an infected disease, isn't it? You're not sick I think, it is Alif who infected Ella today.))

Student: What happen is you?

((This sentence should be corrected))

Teacher: What happen with you bukan is you. What happen with you?

((We say what is happen to you not what happen is you.))

Student : Yes mom!

In extract 1 above, the teacher asked one of her students by saying, "Hey, Ella, why do you look so sad?", which is taken from the third meeting of the transcription. The teacher at that time performed an action to asked one of her students named Ella about her condition at the day. The expression that she said before contains literal meaning to communicate with her students. The expression which the teacher asked the students about her condition can be categorized as locutionary act. Another example of locutionary act can be observed in the following extract:

\section{Extract 2:}

\section{Teacher and students' interaction}

Teacher : "How's life?"

Students : "I'm fine and you?"
Teacher: "I'm fine, nice to hear that, I'm very well thank you!" (cough)

(errrrr) "Rana, please take English book in the library please!"

In extract 2 above, the teacher asked about the students' condition at that time by saying, "How's life?". This expression contains communicative meaning as an expression when teacher greeted the students. Literally, this expression does not need a reply from the students. This expression can also be categorized as locutionary act.

\section{b. Illocutionary Acts}

Illocutionary act seems to be true that it performs the same way to convey information, but then it is different in its content. It contains the social function of what speaker said. The concept of an illocutionary act is central to the concept of a speech act. Although there are numerous opinions as to what 'illocutionary acts' actually are, there are some kinds of acts which are widely accepted as illocutionary, as for example promising, ordering someone, and bequeathing.

In the present data below, it will be discovered about the use of illocutionary act in three kinds of examples. The examples are taken from the transcription of teacher and students' interaction in the classroom during the learning process.

\section{Extract 3: \\ Teacher and students' interaction}

Teacher : Oke, oke.. seat belt, (wow!).. ini saya mau tanyakan nih, kata seat belt, pernah dengar kata seat belt? atau memang pertama kalinya dengar kata seat belt?

((Okey, okey. Seat belt (wow!). I want to ask you, have you ever heard about the word "seat belt"? Or is this the first time you hear about the word?))

Students : (Some students comment) Yes, apa itu seat belt? yes!

"Yes. What is seat belt? Yes!"

In extract 3 above, the teacher asked the students whether they ever heard about a particular word. The teacher expressed it by 
saying, "I want to ask you, have you ever heard about the word "seat belt"? This expression contains a social function, in this case is to ask the students to look for it in the dictionary or try to remember it. It can be categorized as an illocutionary act since it contains a particular request for students to do. Another example of illocutionary acts can be seen in the following extract:

\section{Extract 4: \\ Teacher and students' interaction}

Teacher : Back to your sit please!...(e..).. Fauzan please take your friends book on my table!...

Student : I'm not yet do it, Mom.

In extract 4 above, the teacher asked her students to go to their seats by saying, "Back to your sit please!". The expression contains a particular intention as a command to the students to go back to their seats. This can be categorized as illocutionary acts because it has a social function within the expression. Furthermore, the teacher said another expression by saying, "Fauzan please take your friends book on my table!". This expression also has a social function in it and used by the teacher to ask one of her students to submit his friends' assignments on her desk. It can be categorized also as illocutionary act. Another example of illocutionary acts can be seen in the following extract:

\section{Extract 5: \\ Teacher and students' interaction}

Teacher: The first, we will discuss about the word of road. Jadi yang akan kita bahas pertama adalah mengenai kata road!

((Firstly, we will discuss about the word "road", so the first thing that we will discuss is about that word!))

Student : Road!

In extract 5 above, which is taken from the first transcription of teacher and students' interaction in the classroom, we can find that teacher said another example of illocutionary acts by saying, "Firstly, we will discuss about the word "road", so the first thing that we will discuss is about that word!". The expression is used by the teacher to convey her intention and ask the students that the first thing they will learn is about the word "road". This expression also contains a social function used to command someone.

\section{c. Perlocutionary Acts}

Perlocutionary acts are performed with the intention of producing a further effect on the hearer. Sometimes it may seem that perlocutionary acts do not differ from illocutionary acts very much, yet there is one important feature which tells them apart. It contains also a social function within the expression and act or feedback by the listener as a response to what the speaker says.

In the present data below, it is shown the use of perlocutionary acts by teacher in the EFL classroom during the learning process. The examples are taken from the transcription between teacher and students and it will be discovered within three examples of illocutionary acts below.

\section{Extract 6:}

\section{Teacher and students' interaction}

Teacher : Okey, Fajrul, Gustiawan,.. Dillah!, Andi Nurfadillah, oke, please, come forward.. kata yang kita bahas kali ini adalah safety!

((Okay, Fajrul Gustiawan, Dillah! Andi Nurfadillah, now please come forward in front of the class. The word that we will discuss today is safety.))

Students : (They prepare and come to the white board).

In extract 6 above, the teacher commands two of her students to come forward in front of the class by saying, "Okay, Fajrul Gustiawan, Dillah! Andi Nurfadillah, now please come forward in front of the class. The word that we will discuss today is safety". In this expression, the teacher tried to convey a message in her expression. She commands her students to do what she said and her students do what she commands them. This expression can be classified as a perlocutionary act since it has an intention in the expression and there are responses from the listener to do what the speaker says. The students respond what teacher commands by preparing themselves to 
come forward in front of the classroom and write on the whiteboard. Another example of perlocutionary acts can be seen in the following extract below.

\section{Extract 7:}

\section{Teacher and students' interaction}

Teacher : Oke, everybody back to your seat please. Oke, duduk, duduk. Hmm, oke, Safe driving for life. Ehmm, hmm, hmm.. Rizal, Nur Hairul Rizal, please read paragraph one.

Loud speaker system yah. Paham yah? Loud speaker system kita' pakai.

Safe driving for life paragraph one. Rizal I ask you to read not to laugh. Silahkan.

(("Okay, everybody back to your seat please. Okay, sit down please. Okey, safe driving for life. (ehhmm, hmm, hmm) Rizal, Nur Hairul Rizal, please read the first paragraph!".

"We will use loud speaker system, do you understand it?"

"Read the first paragraph. Rizal, I am not asking you to laugh, read that please".))

Rizal : (Rizal began to read the paragraph while the teacher correct the wrong pronunciation of English word)

In extract 7 above, which is taken from the second meeting of the recording, the teacher conveys an expression to ask her students to do something by saying, "Rizal, Nur Hairul Rizal, please read paragraph one". This expression contains a particular intention used to command someone. It can be classified as perlocutionary act since it contains a social function to command someone and someone that hears it responds it by doing something. As the previous explanation above, perlocutionary act contains a social function within the expression and act or feedback by the listener as a response to what the speaker says.

\section{Extract 8: Teacher and students' interaction}

Teacher: Berarti Rizal bisa, please come forward. Tolong maju kedepan dulu. Rizal bisa bawa mobil kan? Berarti saya minta
Rizal menjelaskan ke kawan-kawan nih about how to drive a car. Silahkan Rizal, come forward please.

((It means that Rizal can come forward to the front of the classroom. Rizal, you know how to drive a car, don't you? Please tell us how to drive a car)).

(Teacher went to Rizal's seat and asked him to come forward. The classroom situation is crowded)

Rizal: (Come forward in front of the classroom and pretend he was driving car)

In extract 8 above, the teacher asked one of her students to come forward in front of the classroom by saying, "Rizal can come forward to the front of the classroom". Within this expression, there is a specific intention that she wants her student to do. She said that to command his students to do what she says and as the result, her student gives a response to her by coming forward in front of the classroom and pretending he was driving a car. This expression can be categorized as perlocutionary act since it has a particular intention within the expression and the listener, in this case Rizal, performed a response to what his teacher commands him.

\section{Conclusion}

Teaching English nowadays is a must for a professional English teacher. It is because teaching is the manner to transfer knowledge from teacher to student. In transferring the knowledge, a professional teacher should master a good way to do it. He should know how to manage the classroom and consequently create a prime atmosphere in the classroom. Besides mastering those things, a teacher should know how to teach with good speech acts. Speech act is everything related to communication that occurred between teacher and students in the classroom, whether it is the way the teachers commanding, explaining something, asking something or managing their students. In this study, the writer explains and observes the speech acts occurred between a teacher and students in EFL classroom. The teacher here was performing three kinds of speech acts proposed by Austin namely locutionary act, illocutionary act and perlocutionary act. Each 
of those speech acts is showed by the teacher while she was teaching in classroom.

Of the three meetings above, it was found that, while the teacher was greeted the students, she performed a locutionary act due to the fact that her expression did not contain any particular intention within. Then, while she asked the student to read some paragraphs in the book, she performed an illocutionary act since the expression contains a certain intention. Furthermore, if the teacher asked the students to be quiet in the classroom and the students obey what she said, then she performed a perlocutionary act. Different from illocutionary act, perlucutionary act here appeared if the listener shows a feedback as response to what speaker says. This study is addressed to both teacher and students in order to make good perspective about speech acts. Hopefully through this mini research, they can perform a good speech act in the process of teaching and learning.

\section{References}

Austin, John L. 1967. How to Do Things with Words, Clarendon, Oxford University Press.

Bach, K., and Harnish, R.M. 1979. Linguistic Communication and Speech Acts. Cambridge, Mass.: MIT Press.

Curtis, Audrey and Maureen O'Hagan, 2005. Care and Education in Early Childhood: A Student's Guide to Theory and Practice. New York. Routledge Falmer.

Hickman, S. 2000. Social Significance of Pattern of Questioning in Classroom Discourse. http://cla.libart.calpoly.edu. Retrived on October. 292012.

Nadar, F.X. 1998. 'Indonesian Learners' Requests in English: A Speech-Act Based Study'. Humaniora. Buletin Fakultas Sastra Universitas Gadjah Mada. No. 9. Yogyakarta: Universitas Gadjah Mada.

Searle, J.R., 1969. Speech Acts. Cambridge: Cambridge University Press.
Searle, J. R. 1979. Expression and Meaning. New York: Cambridge University Press.

Wardhaugh, A. 1992. English speech act verbs: A semantic dictionary. London: Academic Press.

Wells, G. 1985. Language Development in the Pre-School Years. Cambridge: Cambridge University Press.

Yule, G. 1996. The Study of Language. Cambridge: Cambridge University Press. 